\title{
Reduction of forces on the teats by single tube guiding in conventional milking parlours
}

\author{
S. Rose-Meierhöfer ${ }^{\#}$, R. Brunsch and M. Jakob \\ Leibniz Institute for Agricultural Engineering Potsdam-Bornim e. V. (ATB), Max-Eyth-Allee 100, 14469 Potsdam, \\ Germany
}

\begin{abstract}
Udder health considerably affects the economics of dairy farming. There are different reasons for poor udder health; one of them is the milking technique. In earlier studies it was shown that automatic milking systems (AMS) have advantages over conventional milking systems (CMS). Quarter individual milking and automation are therefore possibilities to improve the milking process. Single tube guiding allows controlling each quarter individually to measure cell count or end the process according to the cows needs. This study evaluates the effect of a single tube milking system used in a conventional milking parlour. Forces on the teats regarding different udder formations and vacuum behaviour were recorded. The investigated single tube milking system MultiLactor ${ }^{\circledR}$ is produced by the company Siliconform GmbH, Türkheim, Germany. Balanced allocation of vertical force for all teats is important for proper and gentle milk withdrawal and to maintain udder health. Measurements of force distribution in AMS and MultiLactor ${ }^{\circledR}$ systems proved their superiority to conventional milking clusters. Furthermore, all the other force directions were reduced to nearly zero in AMS and MultiLactor ${ }^{\circledR}$. Higher adaptability to irregular udder formations is also expected. In conclusion "wrong" positioning of the teat cups is expected to be solved by implementing clawless milking clusters.
\end{abstract}

Keywords: Milking techniques, single tube cluster, force, udder health

\#Corresponding author. E-mail: srose@ atb-potsdam.de

\section{Introduction}

Udder health significantly affects the economy of dairy farming. Milk yield, raw milk quality and udder health are the most important quality parameters for the dairy farmer. In the past scientists have specifically been focussing on the relation between machine milking and the development of mastitis. A parlour not functioning to its optimum can increase the risk of mastitis, damages teats and increases overall milking time. In this context the adaptability of milking clusters to different udder formations plays a decisive role as well as liner and vacuum behaviour.

Earlier studies showed that automatic milking systems (AMS) have advantages over conventional milking systems (CMS). A constructive separation of the teat cups enables an even force distribution among all teats especially when irregular udder formations are the case. The implementation of quarter individual milking in conventional milking parlours could be very helpful to reduce somatic cell count (SCC) and udder diseases (Rose et al., 2006). Investigations of Svennersten-Sjaunja et al. (2000) as well as Hamann \& Reinecke (2002) showed a considerable improvement of udder health after converting from CMS to AMS.

The average vacuum level in the claw is the key factor in allowing good milkability (Reinemann et al., 2007) and to sustain udder health. Changes in the teat tissue due to milking can reduce the effectiveness of the natural barrier against infection.

Hamann (1989) emphasized that there are several possibilities of infection during milking: transfer from teat to teat within udder or transfer via teat cup between cows. Infection via teat cup may occur due to milk remains in the liner. Quarter-to-quarter infection is a result of inadequate technical parameters such as the claw volume, the shortness of milk tube, pulsation failures or incorrect vacuum level. To prevent re-spray and corresponding bacteria spread within the udder Baer (1971) and Hamann \& Tolle (1978) suggested quarter individual milking.

Therefore, modifications of milking machines to prevent inter-quarter transfer should be a major contributor to mastitis control (Mein et al., 1992). 
The main objective of this study is to compare the new MultiLactor ${ }^{\circledR}$ incorporating a single tube milking cistern and a conventional milking system by evaluating the vacuum behaviour and the forces applied to the udder.

The results of the force measurements are presented in the publication.

\section{Materials and Methods}

Three different types of milking systems were tested during the experiment: the MultiLactor ${ }^{\circledR}$ (MULTI), a conventional milking cluster (CON) and a type of AMS simulation systems (CON_L) with quarter individual milk tubes. Specifications for the different systems are shown in Table 1.

The single tube milking system MultiLactor ${ }^{\circledR}$ is produced by the company Siliconform GmbH, Türkheim, Germany. Its characteristics are a sequential pulsation rate of 60 cycles per minute, teat cups fitted with silicon liners and a pulsation according to the BioMilker method, which incorporates periodic air inlet into the teat cups.

Table 1 Specification of the three different milking systems evaluated

\begin{tabular}{|c|c|c|c|c|c|}
\hline \multirow[t]{2}{*}{ Milking system } & \multirow{2}{*}{ System code } & \multirow{2}{*}{$\begin{array}{l}\text { Weight of teat } \\
\text { cups with tube } \\
(\mathrm{kg})\end{array}$} & \multirow[b]{2}{*}{$\begin{array}{c}\text { Claw volume } \\
\text { (cc) }\end{array}$} & \multicolumn{2}{|c|}{ System specifications } \\
\hline & & & & $\begin{array}{l}\text { Length and inside diameter } \\
\text { of long milk tube } \\
(\mathrm{mm})\end{array}$ & $\begin{array}{c}\text { System vacuum } \\
(\mathrm{kPa}) \\
\end{array}$ \\
\hline $\begin{array}{l}\text { Conventional } \\
\text { milking cluster }\end{array}$ & $\mathrm{CON}^{1}$ & 3.36 & 160 & $500 / 16$ & 40 \\
\hline $\begin{array}{c}\text { Conventional } \\
\text { with single tube }\end{array}$ & CON_L & 2.17 & - & $1200 / 12 \times 4$ & 40 \\
\hline MultiLactor $^{\circledR}$ & MULTI & 2.64 & - & $2100 / 10 \times 4$ & 36 \\
\hline
\end{tabular}

${ }^{1}$ used as reference milking cluster.

Artificial teats equipped with sensors were used for the measurements. Each artificial teat contains a sensor which measures the vertical force it is being exposed to. The forces are measured with the aid of strain-gauged strips (strip tensometer). Each teat is connected to a measuring transformer and a PC.

Two udder formations were included in the experiment, normal udder and stepped udder. The stepped udder had a difference of $50 \mathrm{~mm}$ in height between the front and rear teats. The laboratory plant allows adjusting different milk flows, however preceding studies have shown that the milk flow has a low influence on the forces. Therefore a milk flow of $5 \mathrm{~L} / \mathrm{min}$ was used for all experiments. The teat cups attached in five repetitions per udder formation in each system.

The resulting data provide the basis for calculating mean values. Paired parametric tests were conducted for the evaluation of differences between front and rear teat pairs. Non-parametric tests were performed for the evaluation of the mean forces of the different systems. The Kruskal-Wallis test was used because of unbalanced data. The MultiLactor ${ }^{\circledR}$ data was compared with the results from force measurements in the conventional and single tube systems. The statistical analysis was carried out with software package SAS 9.1.3, service pack 4 for Windows.

\section{Results and Discussion}

One important reason for udder damages can be the wrong positioning of the milking unit, therefore even allocation of the vertical forces is very important. However, preceding studies have shown that AMS with single tube guiding show a good adaptability to the udder in comparison with conventional milking clusters especially regarding irregular udder formations.

Figure 1 shows the average vertical forces for the three milking systems regarding the stepped udder formation, the average forces on front and rear teats are displayed. The biggest difference between front and rear teats was observed for the conventional milking cluster (CON). However, the small overall differences between front and rear forces for MULTI and CON_L were still significant. Statistical data are shown in 
Tables 2 and 3. The paired Kruskal-Wallis test proved that all three milking systems significantly differ from each other for both udder formations. The difference between MULTI and CON_L was unexpected and we assume that the difference has no influence on udder health. On the other hand the difference of $10 \mathrm{~N}$ between front and rear teats recorded for the conventional system is apt to cause harm to the teat and udder.

Regarding the uneven force distribution in stepped udders Worstorff \& Göft (1989) expected the front teats to be milked out faster because of the higher force put on them. In consequence the rear teats have a higher strip yield. In his research, Johnson (2000) emphasized the importance of regular allocation of the forces to all teat cups.

The results clearly show that in MultiLactor ${ }^{\circledR}$ and CON_L the forces are evenly distributed between front and rear teats. Therefore, a good adaptability to irregular udder formations is obtained for both systems. This can help to prevent damage to the udder and in consequence fewer cases of mastitis.

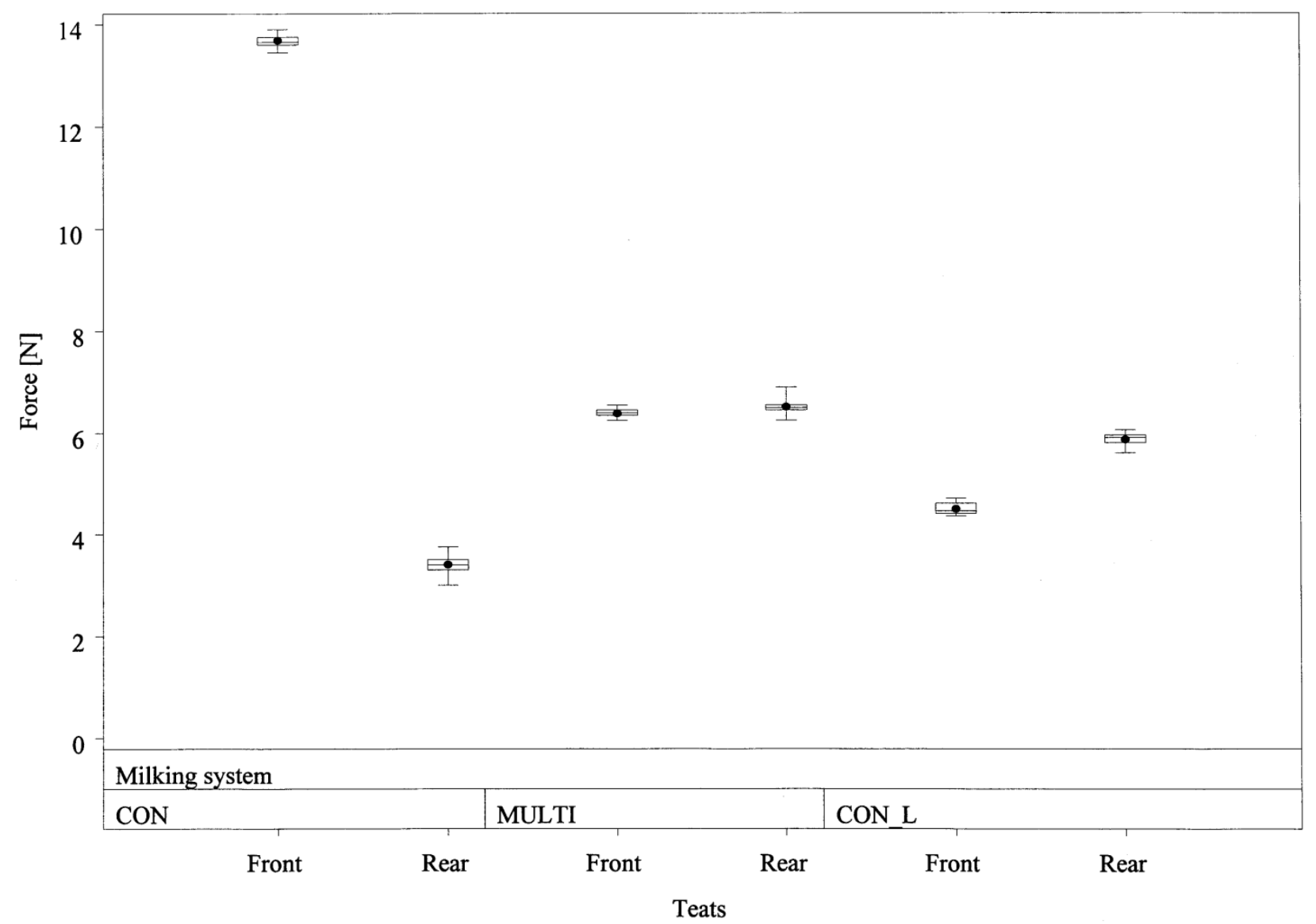

Figure 1 Forces $(\mathrm{N})$ at the front and rear teats in different milking systems.

Table 2 Paired Kruskal-Wallis tests for differences in absolute deviation from equal force distribution on front and rear teats between milking systems (CON - conventional milking cluster; Multi - MultiLactor ${ }^{\circledR}$ )

\begin{tabular}{ccccc}
\hline Udder formation & Contrast & Chi-Square & Pr $>$ Chi-Square & Ranking \\
\hline normal & CON - MULTI & 450,1975 & $<.0001$ & CON $>$ MULTI \\
normal & CON - CON_L & 450,7350 & $<.0001$ & CON > CON_L \\
normal & MULTI - CON_L & 451,3224 & $<.0001$ & CON_L $>$ MULTI \\
stepped & CON - MULTI & 450,0510 & $<.0001$ & CON $>$ MULTI \\
stepped & CON - CON_L & 449,8209 & $<.0001$ & CON $>$ CON_L \\
stepped & MULTI - CON_L & 450,4034 & $<.0001$ & CON_L $>$ MULTI \\
\hline
\end{tabular}


Table 3 shows that all three tested milking systems are significantly different from each other for both udder formations. This was expected because they have different adaptation of the cluster to udder.

Table 3 Kruskal-Wallis tests for differences in deviation from equal force distribution on front and rear teats within milking systems

\begin{tabular}{ccccc}
\hline Udder formation & Contrast & Chi-Square & Pr $>$ Chi-Square & Ranking \\
\hline normal & CON & 224,4689 & $<.0001$ & $\mathrm{~F}>\mathrm{R}$ \\
normal & CON_L & 225,7261 & $<.0001$ & $\mathrm{R}>\mathrm{F}$ \\
normal & MULTI & 224,5275 & $<.0001$ & $\mathrm{R}>\mathrm{F}$ \\
stepped & CON & 224,3751 & $<.0001$ & $\mathrm{~F}>\mathrm{R}$ \\
stepped & CON_L & 224,832 & $<.0001$ & $\mathrm{R}>\mathrm{F}$ \\
stepped & MULTI & 196,6058 & $<.0001$ & $\mathrm{R}>\mathrm{F}$
\end{tabular}

CON - conventional milking cluster; Multi - MultiLactor ${ }^{\circledR}$.

\section{Conclusions}

Wrong positioning of teat cups can be avoided if systems with single tube guidance are implemented. The values of the vertical forces clearly showed the superiority of both single tube systems used for irregular udder formation. In conclusion it can be recommended to use single tube systems in milking parlours for their excellent adaptability to the udder formation besides avoiding turning, tilting or side forces.

\section{References}

Baer von, H.F., 1971. About the infection risk of the mammary gland depending on fluidic terms in milking machines. Dissertation, Tierärztliche Hochschule, Hannover (in German).

Hamann, J. \& Tolle, A., 1978. Infection trials with conventional and non-conventional milking units. Int. Symp. on Machine Milking, National Mastitis Council, Louisville, Kentucky.

Hamann, J. \& Reinecke, F., 2002. Machine Milking Effects on Udder Health - Comparison of a Conventional with a Robotic Milking System. IV-17-IV-27, The first North American conference on robotic milking, 20.-22.03.2002, Toronto, Ontario, Canada.

Hamann, J., 1989. The role of machine milking factors in the aetiology and pathogenesis of mastitis. Hohenheimer Arbeiten, Research on milk production.

Johnson, A.P., 2000. A proper milking routine: The key to quality milk. In: National mastitis council annual meeting, Reno, Nevada, proceedings. p. 123.

Mein, G.A., Bramley, A.J. \& Dodd, F.H., 1992. Machine Milking and Lactation. Insight Books, England, Berkshire.

Reinemann, D.J., Schuring, N. \& Bade, R.D., 2007. Methods for Measuring and Interpreting Milking Vacuum. Sixth International Dairy Housing Conference, Minnesota, USA, electronic only.

Rose, S., Brunsch, R., Schröter, K., Huschke, W. \& Klimetschek, H., 2006. Adaptability of milking clusters to different udder formations in different milking systems. Agrartechnische Forschung 12, S. 53-58.

Svennersten-Sjaunja, K., Berglund, I. \& Pettersson, G., 2000. The milking process in an automatic milking system, evaluation of milk yield, teat condition and udder health. Proc. Int. Symp. Robotic Milking, Lelystad, Netherlands. pp. 277-288.

Worstorff, H. \& Göft, H., 1989. Better milk flow by professional positioning of the milking cluster. Milchpraxis, 27, 1, S. 16-19 (in German, English abstract). 